\title{
De-Constructing Violent Extremism: Lessons from Selected Muslim Countries
}

\author{
Mohd Mizan Aslam \\ Centre for Technology Communication and Human Development (iKOM) \\ Universiti Malaysia Perlis (UniMAP) \\ email:m.mizan@unimap.edu.my /mohdmizan@gmail.com
}

\begin{abstract}
This paper emphasized methods used in deradicalization programs such as holistic personality, self-reflection, social skills, crime behaviour, spirituality, consideration, security and psychology.Deradicalization has increasingly been subjected to scientific studies, but a universally accepted definition of the concept is yet to be developed and defined officially. Nevertheless, there are some definitions developed by the researchers to describe deradicalization. De-radicalization can be understood as the process of changing the attitudes and behaviours of former terrorists to reject violence as an ideological, religious or political goal that may cause harm to national security, affect political and economic instability or pose threats to human life. Many countries have taken significant steps to overcome terrrorism through deradicalization programs such as in Saudi (Al-Ha'ir),Yemen (Al-Hitar) and Malaysia(Pemulihan). Most of the program is based on re-education and rehabilitation. Re-education focuses on correcting political and religious misconceptions of the militants, while the strategy of rehabilitation is adopted to provide a thorough monitoring of the militants after their release. The module of De-radicalization was intended to help government rehabilitate detained militants and help to rebuild their personality.
\end{abstract}

\section{Keywords:}

Deradicalization, Terrorism, Counterterrorism, Extremists

\section{Introduction}

In recent times, the concept of radicalization has increasingly been a subject of scientific studies. Leading to this is the fact that a 
rather more universally accepted definition of the concept is yet to be developed and accepted by scholars. Nevertheless, some definitions have been developed by researchers to describe radicalisation. These definitions of radicalisation are mostly centred around two different foci: 1) on violent radicalisation, where emphasis is put on the active pursuit or acceptance of the use of violence to attainstated goals; 2) on a broader sense of radicalisation, where emphasis is placed on the active pursuit or acceptance of far-reaching changes in the society which may or may not constitute a danger to democracy and may or may not involve the threat of or use of violence to attain stated goals (Veldhuis and Staun 2009). The Federal Bureau of Investigation (FBI) (2006) stated that there are four stages of radicalization which are pre-radicalization, self-identification, indoctrination, and action that have similarities to what has been further explained by (Silber and Bhatt 2007). In a similar vein, Silber \& Bhatt have four levels of the radicalization which consist of the pre-radicalization phase, self-identification phase, indoctrination phase, and jihadization phase.

For as long as a radical ideologies continue to exist in this world, there is the need for a remedy for mitigating and curbing the menace of deradicalization. The importance of the need for it to be in place is essential for every country in order to maintain stability and social integration. In line with this, major steps have been taken by every nation blocks such as United Nations and European Union as well as Southeast Asian countries. The steps lies on the principal approach for tackling deradicalization known as a 'strategy'. The strategy is based on Countering Violent Extremism or CVE. It was designed to cover the threat atmosphere and perimeters of deradicalization. It covers both the preventive and corrective aspects of countering ideologies through law implementations with the active involvement of civil society organizations (CSO). The main objective here is to create an unsympathetic and unfavourable environment for terrorist

DINIKA, Volume 4, Number I, January - April 2019 
operatives with the aim of isolating them from their supporters.

Developments in recent years has revealed that the world is facing a global terrorism challenge which has become a major security issue for most countries around the world. This is because the issue of global terrorism dominates every single country regardless of locality and size. In most cases the main proponent which exacerbate the menace of terrorism is ideology. Ideology is a strong force which could lead people to either act as real human being or as an animals. Dealing with the subject of ideology is always an uphill task and difficult to overcome given the experience of the larger world in previous ideologies like fascism, communism and socialism decades ago. Currently, concerns have been raised as to how to deal with this obnoxious problem known as terrorism. This is because the fight against terrorism often ends up with loss of life, time and money for so many years. These phenomenon are detrimental to social harmony and threatens the whole world. If governments around the world fail to address the problem of terrorism as profoundly as it should, there could be a further detoriation of the problem with the possibilities of it extending into neighbouring countries or elsewhere.

The existence of terrorism depends on two main things, ego and motive. Those who embraced radical and extreme idealism only exist in a state of denial because they hardly agree with contrary opinions and as a result hold on to their views as the only truth. Normally, they don't subscribe to any opposing view or interpretations by scholars other than from the scholars with whom they share the same school of thought. The key problem is that terrorists keep radical views inclusively which often manifests via their extreme narrative towards a sole idea or 'fatwa' of scholar or imams from their own version. Secondly, terrorism requires a political, social, ideological and religious motive. Accordingly those terrorists that acts frequently have an explicit political purpose and commit unlawful attacks for political agenda. This is to say that the primary objective of 
terrorist is the establishment of an Islamic Caliphate or 'DaulabIslamiyyah' as advocated by ISIS, Al-Qaeda, Jemaah Islamiyyah (JI), Kumpulan Militan Malaysia (KMM), Jemaah AnshorutTauhid (JAT), Abu Sayyaf Group (ASG) and many more organized and unorganized terrorists groups.

The most effective remedy for curbing the menace of terrorism is the activation of a deradicalizationprogramme for as long as the radical ideology continues to exist in this world. This has become imperative for every country in order to maintain stability and social integration. In this regard, major steps are being taken by every nation block such as the United Nations, European Union as well as Southeast Asian countries. The method and manner would depend on the deradicalization approaches and 'strategies' for solving the menace. One of the main strategies or techniques is the adoption of the Countering Violent Extremism approach or CVE. The strategy was designed to cover the threat atmosphere or perimeter. It covers both the preventive and corrective aspects of countering deadly ideologies through law implementations and the involvement of civil society organizations (CSO). The fundamental objective is to create an unsympathetic environment for terrorist operatives and an unfavourable environment for their supporters.

Deradicalization requires long term effort by various departments of government as well as from private agencies. Strategically, deradicalization initiatives consist of community engagements for the prevention of extremist from nurturing terrorism related ideas. Therefore, the deradicalizationprogramme is an effort to help build social resilience rehabilitation and reintegration programmes to de-radicalise terrorists and extremists. While community engagement remains a crucial instruments for preventing extremism, disengage terrorists from violent action, it serves as a rehabilitation attempts for tackling radical ideologies and misunderstood concepts. This is by way of instilling appropriate defence mechanism in the detainees and imparting universal values to prevent manipulation by

DINIKA, Volume 4, Number I, January - April 2019 
terrorist organisations. Empirical evidence has shown that some countries are developing different facets of terrorist rehabilitation programmes, focusing on ideological, religious, educational, vocational, social, creative and psychological issues that caused violent extremism.

\section{De-Constructing}

Every attack by violent extremists, not only destroys lives, devastates families and communities, causes destruction of land and livelihoods, but by sowing the seeds of intercommunal suspicion, intolerance and retalition, also contributes to global insecurity and instability including countries in Southeast Asia region. Despite increased securitisation, surveilance, monitoring and various counter-terrorism programmes, the problem shows no signs of abating, but seems to increase year on year. While there may well be success stories of terror plots being foiled, radicals channelled into deradicalizationprogrammes, the unfortunate fact is that countless young people remain vulnerable to extremist propaganda especially through social media. In Southeast Asia, we are particularly concerned about home-grown terrorists radicalised online and offline to embark on any kind of attacks.

The issues related to terrorists and extremists, particularly militant IS or Daesh, have opened up a new chapter of the world's view of Islam, as well as sparking 'Islamophobia'. In the context of IS or Daesh, their supported ideology has led to violence and actions that are incompatible with the true teachings of Islam. The mental disillusionment in the identification of the identity that occurred among the Muslim community itself has made this terrorism very productive and fast-paced. Hence, the understanding of these issues and relating issues pertaining violence is necessary at every level of society. With that understanding, the elements of malice that infiltrate into society can be overcomed and eliminated immediately.De-radicalization can be understood as the process of 
changing the attitudes and behaviours of former terrorists to reject violence as an ideological, religious or political goal that may cause harm to national security, affect political and economic instability or pose as a threat to human life. However, many scholars had defined de-radicalization differently. According to (Ashour 2015), de-radicalization is "the process though which a radical group reverses its ideology and de-legitimizes the use of violent methods to achieve political goals while moving towards an acceptance of gradual political and economic changes within a pluralistic context."

It can be seen that de-radicalization has given new impetus to former militants by teaching them how to lead a normal life and adhere to the religion that emphasizes the oneness of God, faith in unseen things, encouragement to do good, shun evil and rewards its followers by allowing them into heaven on the day of judgement as promised by God. In addition, it is consistent with the teachings of religions especially Islam that encourages every believer to practice moderation in all actions in order for them to earn rewards and enter paradise on judgement day as promised by God. Unfortunately, the ideology that is rooted in their radical teachings encourages the use of violence, risking the lives of innocent people which represents nothing but the cruel wish to meet the demands, interests and aspirations of unscrupulous individuals.

Meanwhile, (Neumann 2010) explains the importance of society's acceptance of former terrorists to determine whether the implementation of de-radicalization programmes would be a success or failure. In most of the time, after the de-radicalization program finishes and the former terrorists, re-join society, it is difficult for them to get public acceptance due to the fears the society feels towards them that they might still not have fully recovered despite undergoing de-radicalization program or might be nursing a private agenda to return to the militant group. Public reluctance to accept former terrorists back into society could also reflect the notion

DINIKA, Volume 4, Number I, January - April 2019 
that it is harder to disengage individuals who live in hostile and troubled areas. Worthy of mention here in particular is the process of disengaging someone who stays in a democratic society like Australia or Great Britain.

\section{A Comparative Method}

This study will be focusing on the deradicalization initiatives taken by Saudi, Yemen and Malaysian government who try to tackle counteringviolent extremism (CVE) through terrorist rehabilitation approach. Through building wide networks of support, the government garnered volunteers from various government and NGO organisations as well as community engagement. It is believed that 7 components of the programme named Modes of Rehabilitation have been implemented as essential component in Saudi, Yemen and Malaysia's broader counterterrorism efforts".

\section{Modes of Rehabilitation}

In order to understand further on the practice of deradicalization process by those three countries, Figure 1 below shows the components clearly.

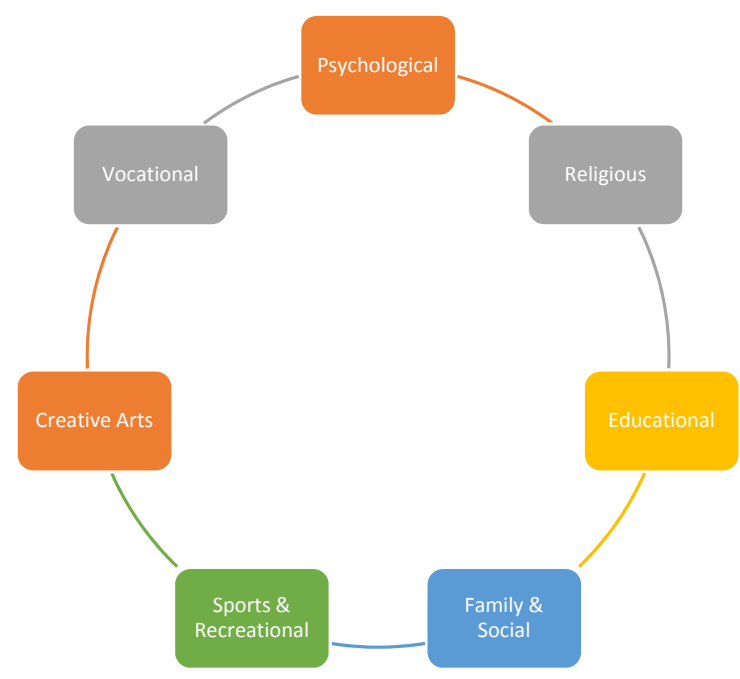

Figure 1: Global Deradicalization approach. Source: (Mohd Mizan Aslam 2018)

DINIKA, Volume 4, Number I, January - April 2019 
From Figure 1, there are 7 modes of terrorist rehabilitation approaches currently employed by governments and agencies globally. Empirical evidence has also shown how different countries are developing different facets of terrorist rehabilitation programmes. The varied rehabilitation modes could be focusing on ideological, religious, educational, vocational, social, creative arts therapy, sports and recreation and psychological factors that could cause violent extremism. These are implemented depending on the recommendations, availability of resources and acceptance by the implementing bodies.

The Saudi for example, has a comprehensive rehabilitation approach. The home secretary created a strategy known as the al-Hair which is described as "a correctional rehabilitation institution intended to develop knowledge and behavioral skills through a set of programs delivered by advisors specialized in different areas of related sciences". The center offers four to six months of programs which include: psychological, social, history, art therapy, self-development as well as 'Online Engagement' as part of their rehabilitation initiatives. The government voluntary program, run under the auspices of the Home Affair, is a programme where qualified scholars are hired to enter online chat rooms for holding discussions with users on Islam. This caters especially for those seeking religious knowledge and clarification, wherein, for example, they discuss the dangers of takfiri (apostasy) ideas.

When implementing deradicalisationprogrammes, each state has different concerns and considerations that will shape their choice of framework as well as the contents for implementation. The Yemen government throuh al-Hitarprogramme has worked closely with the private sector as a facilitator for the rehabilitation of terrorist through a multi-faceted programme. They have rehabilitated and reintegrated hundreds of Syria and Iraq alumnus as well as terrorism related convicts. These detainees went through intensive rehabilitation, studied and were eventually transformed into productive citizens.

DINIKA, Volume 4, Number I, January - April 2019 
Al-Hitar rehabilitation programme consists of three components: psychological rehabilitation, religious rehabilitation, and social rehabilitation. Throughout the detention period, detainees are visited regularly by psychologists who provide psychological counselling and assess their ability to cope with the mental stress of detainees. This allows psychologists to delve into the detainees' psychological reasoning thus assessing their inclination for hatred and violence as well as susceptibility to radical influences. Trained psychologists are also involved in doing proper assessments of behavioural and cognitive aspects of the detainees' progress during rehabilitation.

\begin{tabular}{|c|c|c|c|c|c|c|c|}
\hline Country & 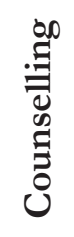 & 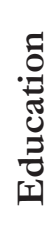 & 宸 & 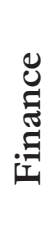 & $\begin{array}{l}\frac{2}{0} \\
\frac{0}{0} \\
\dot{n}\end{array}$ & 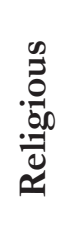 & 丞 \\
\hline Malaysia & 1 & 1 & I & 1 & 1 & 1 & \\
\hline Indonesia & 1 & & 1 & 1 & 1 & & \\
\hline Singapore & / & / & I & & & I & \\
\hline Thailand & I & & & & & & \\
\hline Yemen & I & & & & I & I & \\
\hline Saudi Arabia & I & I & I & I & I & I & 1 \\
\hline Germany & 1 & & 1 & & & & \\
\hline Great Britain & / & & & & I & I & \\
\hline
\end{tabular}

Figure 2: Comparative Global De-radicalization Programs in selected countries. Source: (M.M. Aslam 2017)

Meanwhile, Malaysian de-radicalization initiative was introduced through the Religious Rehabilitation Program. Most of the program is based on re-education and rehabilitation. Re-education focuses on correcting political and religious misconceptions of the militants, while the strategy of rehabilitation is adopted to provide a thorough monitoring of the militants after their release (Noor and Hayat 2009). The family members of the detainees are also engaged in the process as beneficiaries 
of financial support while the militants are in detention. After their release, militants are also assisted with reintegration into the society. This process contributes to a better understanding for the parties involved about the de-radicalization program.

The main entity responsible for conducting de-radicalization programs in Malaysia is The Royal Malaysian Police (RMP). The process involves a few stages. After the arrest of detainees have been made, they are taken to the RMP (Special Branch Department) at Bukit Aman, Kuala Lumpur for interrogation. The quality of the information obtained from the RMP is therefore assessed and processed after which the detention of the detainees is recommended under the ISA for two years (minimum). However, what is presently obtainable is that the ISA is replaced by POTA and SOSMA. Depending on the information given by the detainees which may lead to more arrest more particularly at this stage. Thereafter, detainees are confined to amRestriction Order (RO) after release while some may be released unconditionally subsequently. Some form of counter strategies are also implemented by the Malaysian government with cooperation among the RMP (special branch department), the prime minister's department, the department of Islamic development Malaysia and other relevant government agencies.

According to Malaysia's Inspector-General of Police (IGP), Datuk Seri Muhammad FuziHarun, as well as the then RMP Special Branch Director, rehabilitation and de-radicalization programs in combating terrorism and extremist violence have shown a positive sign in Malaysia since they have achieved almost 95 per cent success rate. Most of the detainees that were released have been successfully reintegrated and returned to mainstream society while only five per cent of the released detainees were reported to have returned to their old way of life. The special branch director also said the rehabilitation period must comply with legal provisions under the Prevention of Crime Act (POCA) and

DINIKA, Volume 4, Number I, January - April 2019 
Prevention of Terrorism Act (POTA) known as a protection order. In a bid to avoid relapse situation which could jeopardise the nation's security, this provision is used to give as much support as possible to the detainees or their family members.

\section{Module for De-Radicalization}

The module for de-radicalization was launched with the intention to help government rehabilitate detained militants and help to rebuild their personality. Among the areas that will be emphasized in this module are holistic personality, self-reflection, social skills, crime behaviour, spirituality, consideration, security and psychology. From the study, both countries Yemen and Saudi implemented a model of deradicalization as can be seen below. Seven key approaches has been implemented, however the Malaysian approach is broader since its covers the main part which is spirituality. Taken into consideration is the fact that the real meaning and true concept of Jihad, Wasatiyyah (moderate) and faith has been covered in the rehabilitation programmes in prison and community based engagements. This approach can be implemented in UK by scholars and academicians. It can be explained through this Figure 3: 


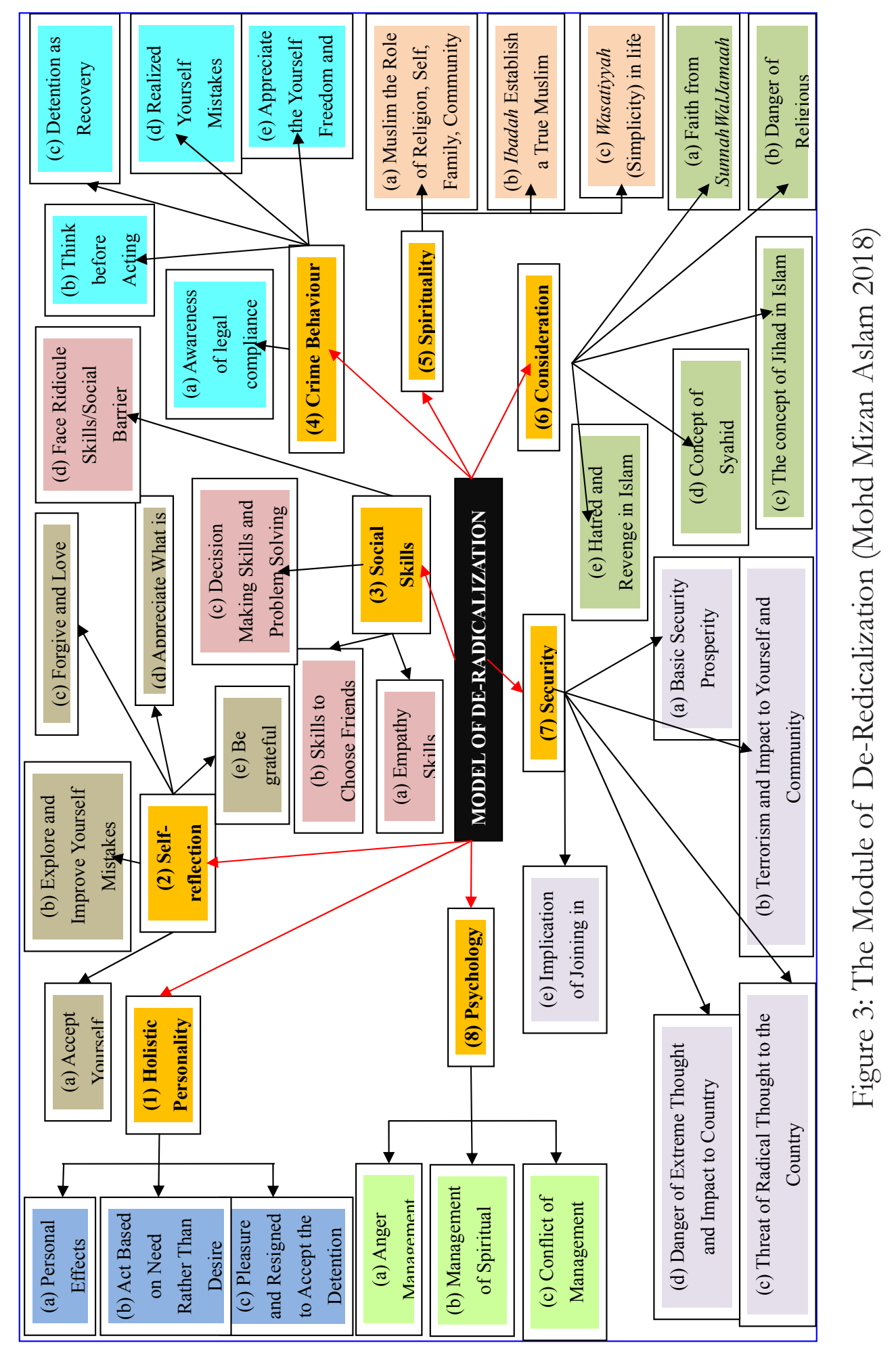




\section{Challenges in Terrorist Rehabilitation}

Although rehabilitation and reintegration initiatives from many countries like Saudi Arabia, Sri Lanka, Denmark, Yemen and others have seen successes, many governments are still not willing to invest in the soft approach. Rehabilitation is a long-term commitment; it requires substantial resources and trained people to implement these programmes.

In some countries, religion is seen as something that should remain in the private sphere. It is a fallacy to perceive religious rehabilitation mode as strictly focusing on religion. While counsellors do preach about Islam, the program content is focused on deradicalisation. The studies of the different country programmes showed that you cannot pull someone away from extremism unless you cover and address all possible reasons that could have driven them to engage in violence and extremism. It is impossible to guarantee that rehabilitation will bear a definite success in bringing the former terrorist to normalisation and be able to function as a normal citizen. This would require a conscientious and well planned implementation. Each detainee is unique in his path to radicalisation, therefore, having dedicated case officers to address individual needs is a start to a new beginning.

These countries has develop their strategy in countering terrorism using de-radicalization model. This study has identified the best method can be used by these countries as well as exported globally. Both have their own advantages blended in indigenious context that suit with local etremists. I believe the soft approach to countering terrorism must be positioned strategically. It is pertinent for governments to introduce both 'preventive and corrective measures' in addressing violent extremism. The challenges today are to ensure terrorists which rehabilitated in the most appropriate way to bring them back into the society and become a part of the larger community in contributing to their religion, race and country. 
Deradicalization has to be pragmatic and dynamic. Those who involved in extremism always in the state of evolution, they become talented and sofisticated because of social media and technologies.The spread of end-to-end encrypted, telegram, twitter and virtual private network(VPNs) as well as dark and deep web has significantly contributed in this problem. Rehabilitation has to implement all of these technologies in their programmes in order to success. New method need to be embedded in their system in order to ensure the quaity and effectiveness of the program. Countries whobelive in this evolution have a bigger percentage to success compare to those haven't. Counsellors, Ustazs, prison officers and every individuals involved in deradicalization has to be well equipped to incorporate technological conditions into their rehabiltationprogrammes.

Some these terrorists, they are naive and know nothing about Islam, they only learn about so called the true teaching of Islam through internet and social media. Their access to the internet has changed the landscap of radicalization and terrorist attacks. Online platform facilitate borderless radicalization and create more 'lone wolf' attackers. Nowdays, radicalition much more easier than before, these people no need to be transported to 'Jihad' field or conflict zone, it is enough only to stay infront of computer with internet facility. Instructions and communications happened through machine end-up with bombings and running over pedestrians as what had happened in Nice truck attacks in 2016 and Westminster attack in 2018.

Saudi, Yemen even Malaysia have to be ready with returning Jihadi fighters from ISIS heaqurters in Syria and Iraq. But don't forget those who comeback from Afghanistan and caucasian countries. Most of these people were equipped with guerilla warfare tactics gained during their stay in those countries. Maktab al-Khidamah and Firqah or special class for learning this skills was implemented in every single conflict zone. Moreover, these fighters also learned how to make home-made bomb such as pipe and tupperware bomb, very conventional but influential in

DINIKA, Volume 4, Number I, January - April 2019 
killing and gain attention from mass people. Recently they also learned to make and use phone and watch detonated bomb as happened in Moovida Nightclub attack in Malaysia and kuningan bombing by Taufiq Abdul Halim, Malaysian exiled in Indonesia. Similar attacks done by Jihadists in Hodaidah, Mukalla\& Aden attacks as well as 2015 car bombing in Sana'a. Saudi, the home of Salafism using Sheikh Muhammad Abdul Wahhab teaching as main character in their practice was produce a significance numbers of terrorists. Since 1960s a score of terroristsattacts happened each year. Al-Yasmin attacks, Al-Qatif and Jeddah Suicide bombing done by those who supported the ideology of ISIS.

Most of them are returning Jihadi fighters, they will gather around and create more chaos and attacks in their homeland or any designated jihad battlefield in neighbouring countries. Re grouping of these fighters has to be monitored because of their ability in doing guerilla style of attacks as well as create home-made bombings. This is a vital role by police personnel in monitoring and surveilance activities. However the most important part is in rehabilitation programs after they have been detained.

A specific and 'taylor-made' deradicalization program have to be in place.Well equipped experts in handling returning extremists need to be hired by Prison Department. Rehabilitation methods need to be changed as previous method considered unsuccessfull. If the same method been used, definetely the deradicalization objectives to detainees cannot achieved.

Malaysia proudly said more than $95 \%$ successful on deradicalization programmes compared to many countries including Yemen and Saudi. Luxury and leisure kind of rehabilitation style in Saudi completely not suitable in Malaysi climate. Saudis, who are always live in confortable and nice condition of life need more relax and soft approach as what had been implemented in most of their Terrorism Rehabilitation Programme so called Al-Ha'ir. Harsh and rough approach by Prison Officers of Yemen 
much more suitable to Yemenis rather than Malaysia.Programe called AlHitar implemented by Yemen government to cater returning Jihadists as well as those involved in Houlthi's movement in southern Yemen.

Another aspect in deradicalization that most of the government not really pay attention with is enforcement and legal aspects. Some countries like Malaysia, Singapore and America have preventive law such as SOSMA, ISA and Patriot Act. However most of the countries in the world have no preventive law. Moreover, some countries violate preventive law in order to achieve their political objectives. United Nation Human Rights Office keep telling Malaysia, Yemen and Saudi in practising the right of people above the law, otherwise it can be abuse by any parties. Some of the colonial law are not suitable in today's world and need to be changed. Terrorists inmates under these law have different mindset as they always think they are not at fault. Right approach by prison personnel to these people are vital and vibrant for the sake of humankind.

\section{Conclusion}

In conclusion, it is safe to mention that Saudi, Yemen and Malaysia has develop their strategies in countering terrorism using the deradicalization model. This study also identified the best method which can be used by these countries as well as exported globally. Both countries have their own styles and advantages blended in indigenous context that suit with local extremists. The soft approach and community engagement to countering terrorism must be positioned strategically. It is pertinent for governments to introduce both 'preventive and corrective measures' in addressing violent extremism. The challenges today is how to ensure that terrorists which are rehabilitated in the most appropriate way are brought back into the society and become a part of the larger community in contributing to their religion, race and country.

DINIKA, Volume 4, Number I, January - April 2019 
Appropriate methods or programs such as de-radicalization has the potential to reduce societal involvement in developing the militant propaganda which is threatening the stability of national and international security particularly in Middle East and Malaysia. Improvement of existing modules in the de-radicalization program is seen as crucial to instill patriotism among former terrorist prisoners so that their past actions is not imitated by young people in particular. Not to forget, every entity should look into the family or parents of the 'terrorists'. If the family is still radical, precautionary measures should be taken into account because there is a strong possibility that other children or adults will constitute a new breed of terrorists. Besides, by sharing the experiences of former terrorist prisoners, the society can also raise awareness on the dangers of radicalism in order to avoid being stuck in this deteriorating and awkward situation.

The state has the obligation and primary responsibility to prevent and combat terrorism, as well as to respect and protect human rights and fundamental freedoms. However, the state needs to draw on the support of society in general, including civil society and businesses, to successfully counter this phenomenon. Countering violent extremism participating entities have acknowledged the usefulness of such joint efforts in the form of public-private-community partnerships in countering terrorism particularly in Southeast Asia region.

There has been a growing recognition that the broader public and individual communities are stakeholders and partners in countering terrorism, rather than simply the passive object of law enforcement activities. Southeast Asia are developing community-oriented approaches to countering terrorism that emphasize public support and participation in order to increase accountability and effectiveness. These approaches consist of locally tailored and locally driven initiatives that draw on partnerships among a wide range of actors, beyond traditional security 
practitioners, to include other public authorities, as well as civil society organizations, businesses and the media.

\section{References}

Ahmad, Azyyati. 2016. "Jabatan Imigresen Perkukuh Tiga Strategi Bendung Rasuah di Kalangan Pegawai.” Astroawani.com. 2016. http:/ / www. astroawani.com/berita-malaysia/jabatan-imigresen-perkukuhtiga-strategi-bendung-rasuah-di-kalangan-pegawai-120355.

Ashour, O. 2015. "Deradicalization Revisited." Washingtonpost. 2015. https://www.washingtonpost.com/news/monkey-cage/ wp/2015/02/18/deradicalization-revisited/?utm_term =. a $874 d 255762 d$.

Aslam, M.M. 2009. "A Critical Study of Kumpulan Militant Malaysia, Its Wider Connections in the Region and the Implications of Radical Islam for the Stability of Southeast Asia." Victoria University Of Wellington, New Zealand.

- 2016. The Threat of DAESH in Malaysian Higher Education Institutions. Kuala Lumpur: MyRISS Special Report to Ministry of Higher Education Malaysia.

. 2017. "The Threat of Daesh in Universities: Malaysia's Experience." A Journal of the International Centre for Political Violence and Terrorism Research 9 (4): 13-16.

Aslam, Mohd Mizan. 2018. A Model of Deradicalization in Malaysia. Edited by Rohan Gunaratna and Sabariah Husin. London: Routledge.

"Authorities Yet to Receive Ransom Demands for Tugboat Crew Members From Sibu." 2018. Theborneopost. 2018. http://www. theborneopost.com/2016/04/03/four-sarawakians-kidnapped/.

Bakri, Mohd, and Mohd Zinin. 2010. "Jenayah dan Isu Pemerdagangan Orang di Kalangan Warga Asing." In Seminar on National Resilience (SNAR 2010) Political Managements and Policies in Malaysia. 22 September 2018. http:/ / repo.uum.edu.my.

Bernama. 2016. "Pembinaan Pagar Keselamatan Sempadan MalaysiaThailand Masih Peringkat Kajian.” Astroawani.com. 2016.

DINIKA, Volume 4, Number I, January - April 2019 
Pembinaan-keselamatan-sempadan-malaysia-thailand-masihperingkat-kajian-106479.

Bruce, G. 1968. The Stranglers; The Cult of Thuggee and Its Overthrow in British India. New York: Harcourt, Brace \& World.

Chasdi, Richard J. 2018. Corporate Security Crossroads; Responding to Terrorism Cyberthreats, and Other Hazards in the Global Business Environment. California: Praeger.

Clutterbuck, L. 2010. "Deradicalization Programs and Counterterrorism: A Perspective on the Challenges and Benefits." Mei.edu. 2010. https://www.mei.edu/sites/default/files/Clutterbuck.pdf.

Crime, United Nations Office on Drugs and. 2004. "United Nations Convention Against Transnational Organized Crime and the Protocols Thereto." Unodoc.Org. 2004. http://www.unodc.org/ documents/treaties/UNTOC/Publications/TOC Convention/ TOCebook-e.pdf.

Fannin, Leon F. 1989. "Thuggee and Professional Criminality." Michigan Sociological Review 3: 34-44.

Gunaratna, Rohan, and Mohamed Bin Ali. 2015. Terrorist Rehabilitation: A New Frontier in Counter-Terrorism. Singapore: World Scientific Publishing.

Gunaratna, Rohan, and M.S. Hussin. 2018. International Case Studies of Terrorist Rehabilitation. London: Routledge Taylor \& Francis Group.

Gunaratna, Rohan, J. Jerard, and S.M. Nasir. 2013. Countering Extremism: Building Social Resilience Through Community Engagement. London: Imperial College Press.

Gunaratna, Ruchina. 2015. Countering Violent Extremism: Revisiting Rehabilitation and Community Engagement. Singapore: Counter Terrorists Trends and Analysis (CTTA).

Hassan, Muhammad Saufi. 2016. "Bebas Rasuah 3 Tahun Lagi." Hmetro. Com. 2016. my/node/188277.

Kassim, Azizah. 2015. "Pendatang Asing Tanpa Izin (PATI) Sebagai Musuh Nomor Dua Negara." In Migrasi dan Keselamatan, edited by Nor Azizan Idris and Zarina Othman, 25-49. Kuala Lumpur: Dewan Bahasa dan Pustaka.

Kohler, D. 2016. Understanding Deradicalization: Methods, Tools and Programs for Countering Violent Extremism. London: Routledge Taylor \& 
Francis Group.

Mohammed, Nasrudin. 2016. "Keselamatan Sempa dan Isu Semua.” 2016. rencana/kawal-lambakan-pekerja-asing-di-malaysia-1.367135.

Mustaffa, Mahfudzah, Rashila Ramli, and Zaini Othman. 1999. Penghantar Hubungan Antara Bangsa. Bangi: Pusat Pengajian Jarak Jauh, Universiti Kebangsaan Malaysia.

Neumann, Peter R. 2010. "The Trouble with Radicalization.” International Affairs Journal 89 (4).

Noor, S., and S. Hayat. 2009. Deradicalization: Approaches \& Models. Jakarta: Pak Institute of Peace Studies.

Passas, Nikos. 2003. "Upperworld and Underworld in Cross Border Crime." Security Journal.

Shurentheran, Vanesha.2017. "Khalid:Pengganas MalaysiaMahmudAhmad Mungkin Lari dari Marawi.” Freemalaysiatoday. 2017. http://www. freemalaysiatoday.com/category/bahasa/2017/06/26/khalidpengganas-malaysia-mahmud-ahmad-mungkin-lari-dari-marawi.

Silber, M., and A. Bhatt. 2007. "Radicalization in the West: Homegrown Threat."

Utusan. 2016. "Membenteras Jenayah Rentas Sempadan.” 2016. www. utusan.com.my.

Veldhuis, Tinka, and Jorge Staun. 2009. Islamist Radicalization: A Root Cause Model. The Hague, Netherlands: Netherlands Institute of International Relations Clingendael.

Waltz, Kenneth N. 2008. Realism and International Politics. New York dan London: Routledge.

DINIKA, Volume 4, Number I, January - April 2019 